\title{
複合基礎の地震応答解析法に関する実証的研究 \\ STUDY ON EARTHQUAKE RESPONSE ANALYSIS METHOD FOR COMPOSITE FOUNDATION OF WALL AND PILE GROUP
}

\author{
福 岡篤信*1, 宮本裕司*2, 酒向裕司*3, 古江 守*3, 安達直 人*4 \\ 喜多村 英司*1, 岩本 賢 治*5 \\ Atsunobu FUKUOKA, Yuji MIYAMOTO, Yuji SAKO, \\ Mamoru FURUE, Naohito ADACHI, Eiji KITAMURA \\ and Kenji IWAMOTO
}

\begin{abstract}
Dynamic characteristics of a composite foundation of wall and pile group are investigated using the results of forced vibration test and earthquake observation. It is clarified that the interior piles show similar vibration mode to that of the wall foundation, and the existence of basement and interior piles restrict the natural vibration of the interior soil. The analytical results using an axisymmetric FEM show the shear force during earthquake is largely burdened by the wall foundation and that is large at the deep part of the soil. The effectiveness of the simplified lumped-mass model is verified through earthquake response analyses.
\end{abstract}

\footnotetext{
Reywords: Composite foundation, Wall-foundation, Pile, Dynamic soil-structure interaction, Forced vibration test, Earthquake observation 複合基礎、地中連続壁、杭、動的相互作用、強制加振実験、地震観測
}

1.はじめに

軟弱地盤に建設される高層建物では、その基礎構造に地中連続壁 (以下、連壁と呼称)をロの字型に配置し、その内外に杭を打設し た複合基礎がしばしば採用される。複合基礎では、周辺地盤と内部 地盤が比較的剛性の高い連壁により分離されること、杭が連壁に囲 まれた内部地盤中に存在すること、一般に高層建物では地下室を有 すること等が、複合基礎の地震応答を複雑にする要因となっている。 複合基礎を有する高層建物の耐震設計を合理的に行うためには、連 壁内部の地盤および杭の動的挙動を明らかにし、地盤と複合基礎の 動的相互作用効果、すなわち慣性の相互作用（INERTIAL INTERACTION）と入力の相互作用（KINEMATIC INTERACTION） 1)を適 切に評価する必要がある。また、複合基礎の耐震性を評価するため には、地震時の連壁、杭に生じる応力の発生機構を明らかにするこ とが必要となる。

複合基礎の応答性状を調べた研究としては、長さ $5 \mathrm{~m}$ 程度の地中 壁体を外周と内部に配置した基礎の地震観測結果に基づく若松ら の研究 2),3)、目の字状の平面を有する連壁の地震観測結果に基づ く阿部らの研究 5)、杭間を連壁で結合して連壁の根入れ効果によ る構造物への入力低減効果を振動台実験により調べた堀田らの研
究 6)などがあり、連壁で囲まれた内部地盤は連壁とほぼ同様な挙動 を示すことが報告されている。連壁で囲まれた内部地盤の挙動を調 べた研究としては、円筒形の連壁を対象に検討した安井の研究 7) や連壁の配置方法をパラメータとして検討した高橋ら ${ }^{8)}$ の解析的 研究がある。また、林ら ${ }^{9}$ は連壁を使用した煙突基礎の振動実験と 地震観測を行い、連壁に囲まれた土が応答に及ほす影響を考察して いる。これらの研究では、内部地盤が基礎の応答性状に影響を与え ることが示されているが、地下室や内部杭は扱われておらず、それ らの効果については明らかにされていない。

複合基礎の動的解析法としては、Penzien らが提案した杭基礎の 解析法を応用した方法 ${ }^{4)}$ 、格子型モデルを用いる方法 ${ }^{10)}$ 、二次元あ

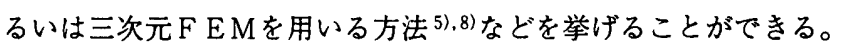
筆者らも、静的三次元 F E M 解析および軸対称 F E Mによる動的解 析の結果に基づいて、連壁と内部杭を 1 本の曲げせん断系にモデル 化した解析法を提案し、実大の複合基礎の強制加振実験結果との比 較によりその適用性を検討してきた ${ }^{11}$ 。

本論文では、新たに実施した地下室を有する複合基礎の強制加振 実験結果と地震観測結果および軸対称 F E Mによるシミュレーシ ヨン解析を通じて、連壁および内部杭の動的挙動に与える地下室、
本論文は，参考文献13）,14)で既に発表したものを加筆したものである。

${ }^{* 1}$ 鹿島 $A / E$ 構造設計部 設計主查

*2 鹿島小堀研究室 主任研究貝・工博

*3 鹿島小堀研究室 研究員

*4 鹿島技術研究所 研究員

*5 鹿島情報システム部
Senior Structural Eng., A/E Structural Engineering Dept., Kajima Corp. Senior Research Eng., Kobori Research Complex, Kajima Corp., Dr. Eng. Research Eng., Kobori Research Complex, Kajima Corp. Research Eng., Kajima Technical Research Institute, Kajima Corp. Intelligent Systems Dept., Kajima Corp. 
内部地盤の影響を明らかにする。また、複合基磁に生じる地霞時応 力について検討するとともに、連壁に生じる応力を建物の慣性力に よる応力と地盤震動による応力に分離して検討する。さらに、筆者 らの提案した解析法に基づく質点系モデルにより地震観測結果の シミュレーション解析を行い、解析法の有効性を検証する。

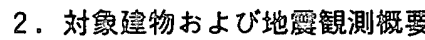

对象建物の複合基硕の杭配置と地震観測点位置を図 1 に示す。建 物は東京臨海部に建つ地上 33 階、地下 2 階の高層住宅であり、平 面形が約 30m 角で高さ約 $104 \mathrm{~m}$ の高層㫫と外周の低層部からなる。 複合基䃈は、高層棟直下に配置された平面形が約 $30 \mathrm{~m}$ 角、厚さ $1.2 \mathrm{~m}$ の連壁とその内部に打設された軸径 $1.8 \mathrm{~m}$ 、拡底径 $3.0 \mathrm{~m}$ の場所打ち 鉄筋コンクリート杭 20 本と、さらに連壁の外側に低層部を支持す る杭径 $0.6 \mathrm{~m}$ の PHC 杭 65 本から構成される。地上部は $\mathrm{R} \mathrm{C}$ 造の純 ーメン構造で、高層栖部分は各杭位置と連壁上部に柱を有する撉形 な架構である。

地霞観測は図 1 に示した高層㭷の 3 フロア（33F, 17F, BlF）と連 壁の 5 深度（GL-12.5m, -16.0m,-19.5m, -23.0m, -26.5m）、内部杭の 3 深度（GL-12.5m,-19.5m,-26.5m）および建物から約 14m 離れた地 盤系の 4 媣度 (GL-1.0m, -15.0m, -20.5m, -27.5m) の加速度について 行っている。また、地盤系（GL-14.3m）と建物直下地盤では間隙水 圧の観測も行っている。水平方向の加速度の計測は X方向を対象に しており、地震観測は建物竣工後から行っている。建物と地盤系の 加速度計はサーボ型加速度計 $\left(\mathrm{f}_{0}=5 \mathrm{~Hz}\right)$ を、連壁、内部杭の加速度 計は動ひずみ型加速度計 $\left(\mathrm{f}_{0}=100 \mathrm{~Hz}\right)$ を使用しており、データ収録 はサンプリング周波数 $100 \mathrm{~Hz}$ でデジタル収録している。

地盤系の地震計設置位置の地盤調查結果に基づく地盤定数を表 1 に示す。地盤層序は地表から約 7m が盛土・埋土、GL-7〜-13m 付 近が下部有楽町層に当たるシルト層、GL-13〜-26m が東京層で粘 性土層と砂層の互層になっており、GL-26m 付近から複合基礎の支 持層となる東京磁層が出現する。N值は、盛土・埋土で 3 9、下 部有楽町層で 0 2 2゙゙あ、颗京層では GL-13〜-14m 付近の粘性土 層で 19、GL-14〜 -19m 付近の砂層で 32〜50、GL-19〜-26m 付近の 粘性土層で 4 19 となっている。

\section{3. 朝対称FEMモデル}

強制加振実験と地震観測結果の解析は軸対称 F E M を用いて行 つた。地霞観湘記録検討時の解析モデル図を図 2 に示す。要素サイ ズにより決まる有効振動数範囲は S 波の $1 / 8$ 波長に対して $10.8 \mathrm{~Hz}$ であり、解析では $8 \mathrm{~Hz}$ までを対象振動数とした。複合基礎の軸対称 モデルへの置換は次のように行った。地下室は剛要素とし、B1Fお よびB2F の面積がそれぞれ等価になる円形基磪にモデル化した。連 壁は B2F 部分と同一の半径で、有効せん断剛性、断面 2 次モーメン トが等価となるシェル要素にモデル化した。杭は群杭として断面 2 次モーメントが等価となるように内部杭を 2 重、外部杭を 1 重のリ ングパイル要素 ${ }^{12)}$ に置換した。地盤モデルの側面にはエネルギー伝 達境界を、底面には粘性境界を考慮した。

建物は設計時に使用した立体精算モデルをもとに以下のように モデル化した。立体精算モデルは柱に曲げ・せん断・軸方向変形を、 梁に曲げ・せん断変形を、柱一梁接合部パネルにせん断変形を考虑
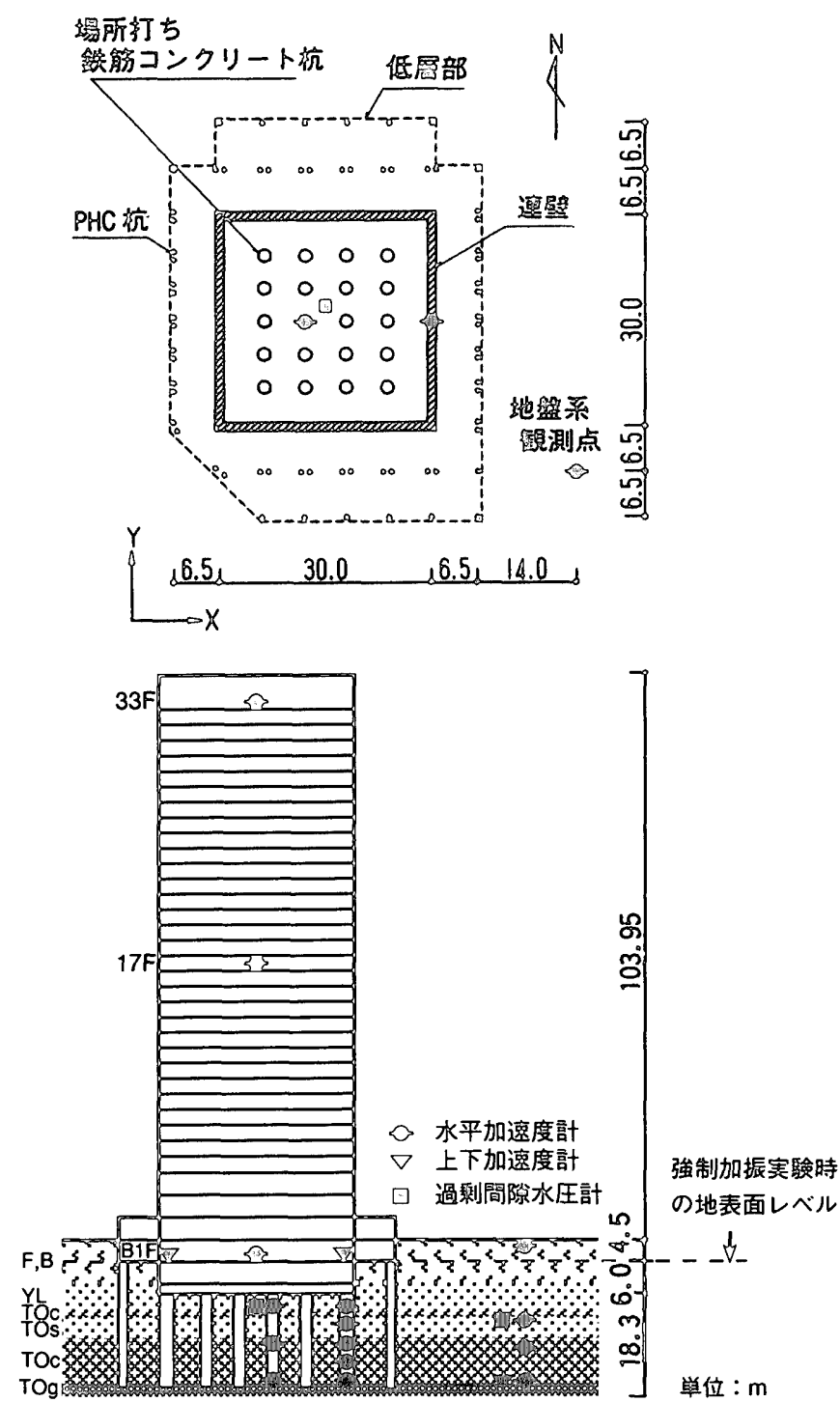

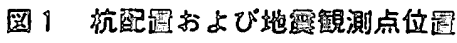

したモデルで、基磂底面位置に軸対称 F E M モデルにより計算され る水平と回転の地盤ばねを接続している。この設計モデルを用いて 得られた固有振動数と後述する地震観測および修正設計モデルに よる固有振動数を比較して、表 2 にまとめて示す。ここで、固有振 動数は $33 \mathrm{~F} / \mathrm{B} 1 \mathrm{~F}$ のフーリエ・スペクトル比のピーク振動数から求め た。観測結果は設計値に比べ 1 次振動数で一割程度高振動数側とな り、高次モードでは差の割合が大きくなっている。この理由として、 各部材剛性の算出根拠としているコンクリート強度を設計モデル では設計基準強度を用いていること、設計モデルでは考慮していな い非構造壁为剛性に寄与していることが考えられる。修正設計モデ ルでは、コンクリート強度として現場水中荃生された供試体の 28 日強度の平均值（設計基準強度の 1.36 倍）を用いて部材剛性を変 更し、さらに非構造壁を考慮して設計モデルを修正した。修正設計 モデルの固有振動数は観測值によく対応していることがわかる。軸 対称F EMモデルでは、立体モデルのX方向に対してねじれの影響 が少ないことから、この立体の修正設計モデルを 1 本の多質点曲げ せん断棒に置換し、減衰は $2 \%$ 複素減衰とした。 
表 1 地盤定数

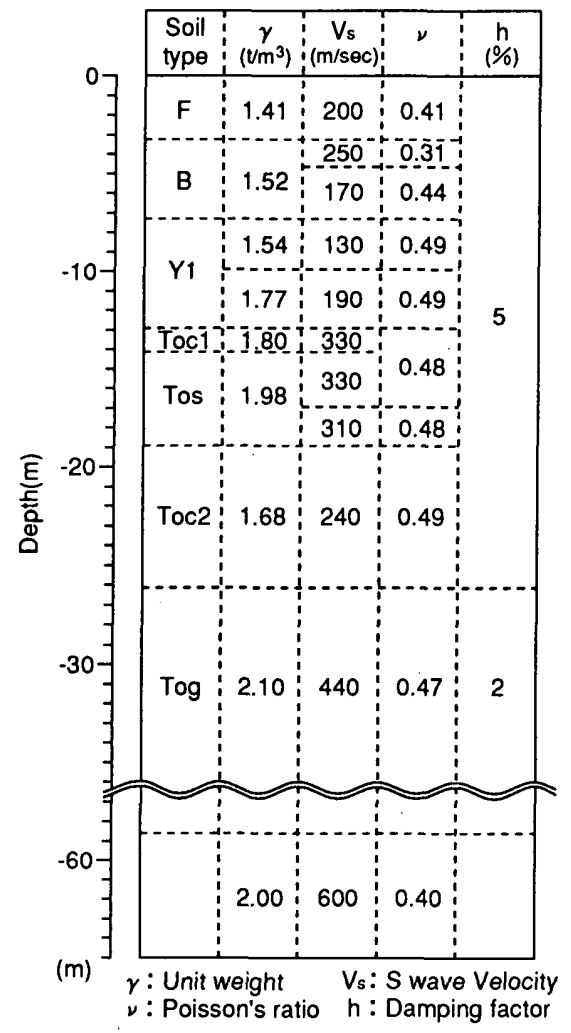

4. 強制加振実験結果の検討

強制加振実験は、BIF の床スラブの施工が完了した段階に実施し た。加振実験時の地表面レベルは図1に示したようにB1Fの床スラ ブ面と同レベル（GL-4.5m）であった。実験は、最大加振力 3 ton の偏心質量一定方式の起振機 1 台を $\mathrm{B} 1 \mathrm{~F}$ の床スラブ中央に設置して、
表 2 固有振動数の比較

\begin{tabular}{|l|c|c|c|}
\hline & 1 次 & 2 次 & 3 次 \\
\hline 設計モデル & 0.53 & 1.67 & 2.86 \\
\hline 観測結果 & 0.59 & 1.94 & 3.47 \\
\hline 修正設計モデル & 0.60 & 1.98 & 3.46 \\
\hline
\end{tabular}

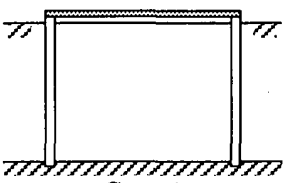

Case-1
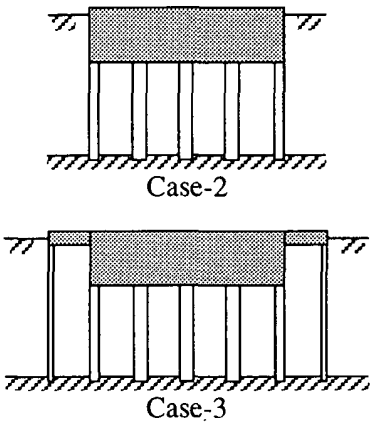

図 3 強制加振実験解析ケース

X方向を対象に実施した。実験では振動数を段階的に上昇させた場 合と下降させた場合を実施し、両者の実験結果に差がないことから、 線形範囲の実験であることを確認した。計測は各階の木上に配置し た水平と上下方向の変位計および地震観測用に連壁と内部杭の深 さ方向に埋設した水平 $(X)$ 方向の加速度計により行った。

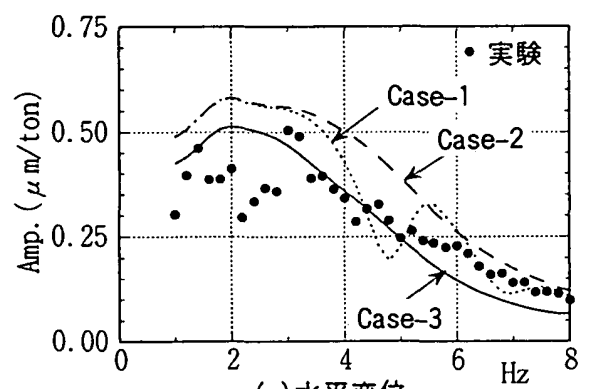

(a) 水平変位

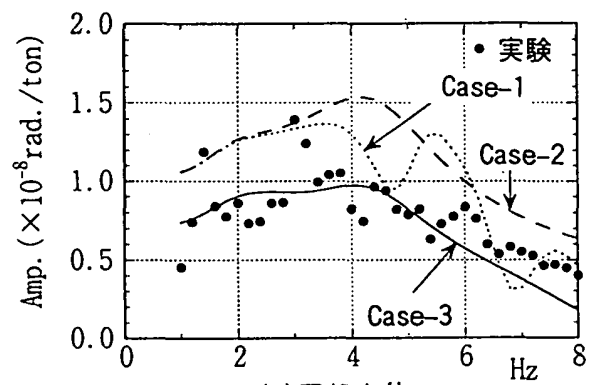

(b) 回転変位

\section{図 4 B1F の共振曲線の比較}

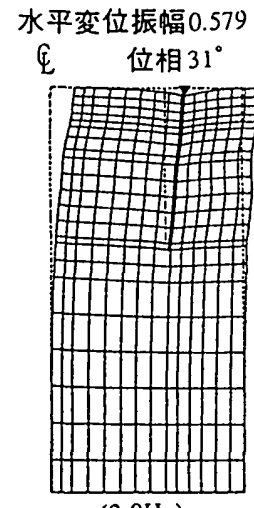

$(2.0 \mathrm{~Hz})$

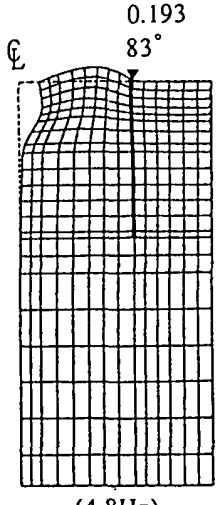

$(4.8 \mathrm{~Hz})$

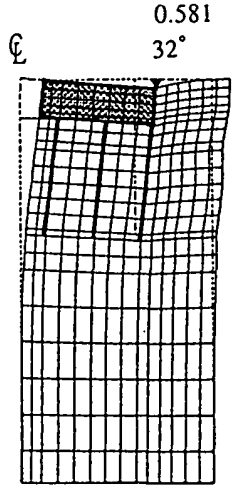

$(2.0 \mathrm{~Hz})$

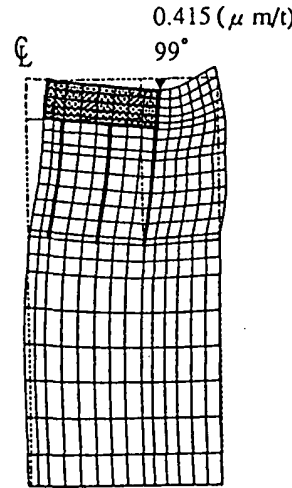

$(4.8 \mathrm{~Hz})$ (b) Case-2

図 5 Case-1 とCase-2の振動モードの比較
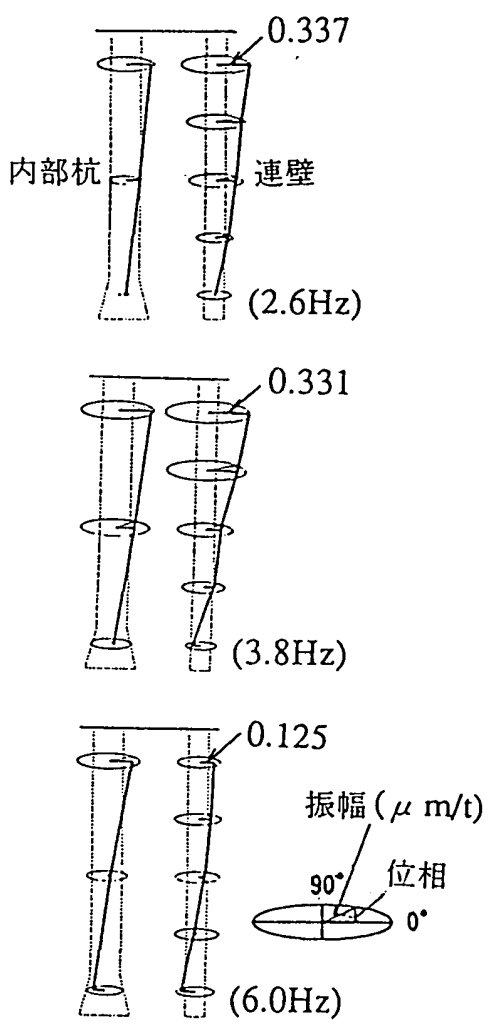

図 6 連壁と杭の振動モード図 
各階床に配置した変位計の計測結果から、各階床スラブはほほ水 平と回転の 2 自由度の剛体振動をしていることが確認できたため、 最小 2 乗法により各階の水平変位と連壁中央 $\mathrm{Y}$ 軸を回転軸とする 回転変位を求めた ${ }^{13)}$ 。解析は、加振実験時の状態に合わせ、B1F 床

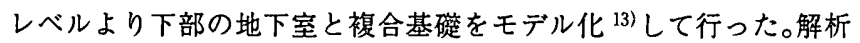
では、地下室の有無と周辺低層部の外部杭が複合基㗏の振動性状に 与える影鉍を検討するため、図 3 に示す 3 ケース (Case-1〜Case3）を実施した。

B $1 F$ 位置の水平変位と回転変位の共振曲線を解析結果とともに

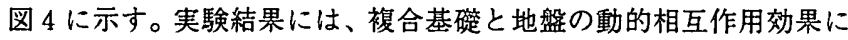
よる大きな逸散減衰のため明瞭なピークがみられない。解析結果に ついて Case-1 と Case-2を比較すると、水平、回転方向とも $3 \mathrm{~Hz}$ 付 近までの低振動数域では両 Case の振幅はほほ一致している。高振 動数域では Case-1 の応答には実験結果にみられない周波数特性が 現れ、Case-2 と様相を異にしている。これらの理由は、図 $5 に$ に示 す振動モードから次のように考えられる。低振動数域では $2.0 \mathrm{~Hz}$ の 振動モード図に示されるように、地下室と内部杭が存在することに よる影㗽は小さく、両 Case とも連壁と内部地盤が一体となった振 動モードを呈し、複合基礴の剛性として連壁の剛性が内部杭の剛性 に比べ支配的であるためである。一方、高振動数域では、 $4.8 \mathrm{~Hz}$ の 振動モード図にみられるように、Case-1 では内部地盤固有の振動 が励起され連壁の振幅が小さくなっているが、Case-2 ではCase-1 において卓越する地表近くの内部地盤の振動が地下室および内部 杭の存在により抑えられているためである。外部杭をモデル化した Case-3 では、Case-2 に比較して周波数特性に大きな変化はみられ ないが、加振振動数全域で基礎の応答が低減し、その違いは水平方 向に比べ回転方向で大きくなっている。この理由として、外部杭の 存在による水平、回転方向の剛性と逸散減衰の增大を挙げることが でき、特に、外部杭の上下抵抗に起因する回転方向の㓮性の增大の 影祀が大きいためと考えられる。また、実験結果との比較では、水 平、回転方向ともCase-3 が実験結果に対応してくる。

図 6 に実験結果から得られた連壁と内部杭の振動モード図を示 す。連壁と内部杭の挙動は各振動数においてほほ同じモードを示し ており、高振動数になるにつれて樑さ方向の湘定点間の位相差が大 きくなり高次モードに移行している。

このように、複合基礎では地下室や内部杭が存在することにより 内部地盤が卓越する固有振動が拘束されること、連壁と内部杭はほ

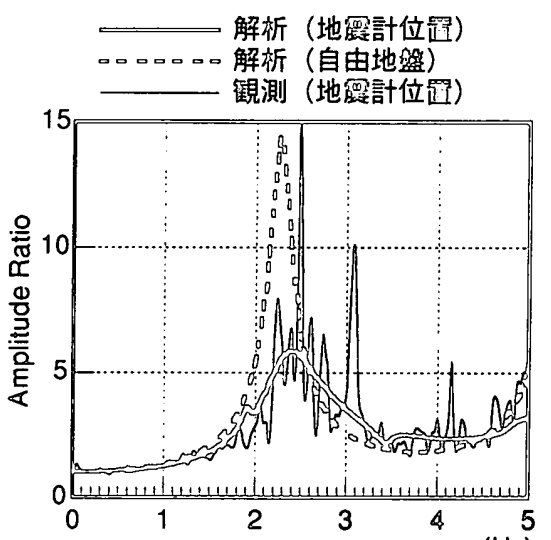

(a) 地盤系 GL-1m/GL-27.5m

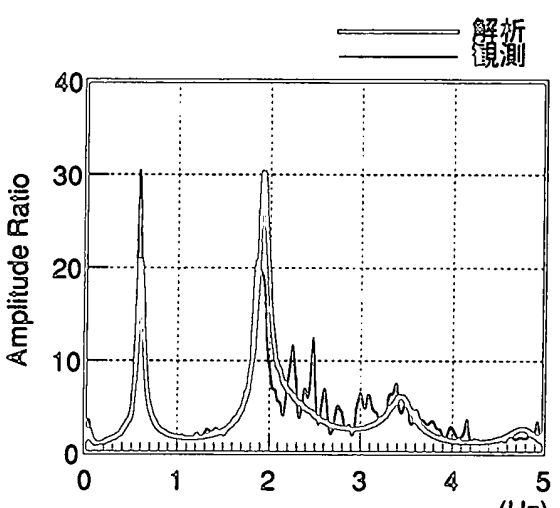

(b) 建䥼 33F/GL-27.5m
ほ同じ振動モードを呈することがわかる。また、本実験のように低 加振力レベルの複合基䃌の応答に、外部杭の存在による水平、回転 方向の剛性と逸散減衰の増大が影響することがわかる。

\section{5。地縹観測記録の檢討}

\section{1 地艋一建物系の応答特泾}

検討対象とした地震は、表 3 に示す 1996 年 9 月に発生した千葉 県東方沖地霞である。地盤系 GL-1m 位置の最大加速度は $20.9 \mathrm{Gal}$ で あった。また、当該地霞時の地盤系のフーリエスペクトル比（GL1m/GL-27.5m）は他の小地震時と有意な差はみられず、過剩間䏚水 圧の発生も認められなかったことから、地盤は線形状態にあったと 考えられる。

解析は、地盤系観測点 GL-27.5m 位置を基準とした伝達関数を算 定し、応答波形は同位置の観測波を伝達関数への入力として求めた。 ただし、後の図 7 の (a)に示すように地盤系の観測記録には複合基 磴の存在による拘束効果が認められたため、伝達関数の基準点は、 軸対称 F E Mモデルにおいて地盤系観測点と建物の位置関係を考 虑し、連壁中心から $42.85 \mathrm{~m}$ でX 軸から 34 度方向の点の X方向成分 とした。なお、以後の観測記録のスペクトルは、建物系の 3 次振動 数までを十分に包含する $5 \mathrm{~Hz}$ までの範囲を示す。

地盤系および地盤一建物系の観測記録のフーリエスペクトル比 を解析結果と比較して図 7 に示す。なお、地盤系のスペクトル比 （GL-1m/GL-27.5m）には、複合基礎の影㗽が無い自由地盤の解析結 果を併記する。地霞計位置の地盤系の解析結果は、自由地盤と比較 しピーク振動数が高くなり振幅は大幅に小さくなる。また、自由地 盤に比べ観測結果とよく対応することから、地震計位置の地盤応答 が複合基路の影響を受けていることが確認できる。33F/GL-27.5m の観測結果には、地盤一建物連成系の 1 次 3 次のピークが明瞭に 認められる。解析結果は 2 次のピークでやや大きめとなるが各ピー ク振動数は対応し、建物の応答性状をよく捉えている。B1F/GL-

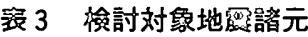

\begin{tabular}{|c|c|}
\hline 発酸日時 & 1996年9月11日11時37分 \\
\hline 零英位置 & 千絜県東方沖 \\
\hline マグニチュード & 6.2 \\
\hline 噈さ & $53 \mathrm{~km}$ \\
\hline 采距離 & $130 \mathrm{~km}$ \\
\hline 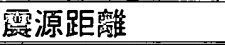 & $140 \mathrm{~km}$ \\
\hline
\end{tabular}

图 7 フーリエスペクトル比

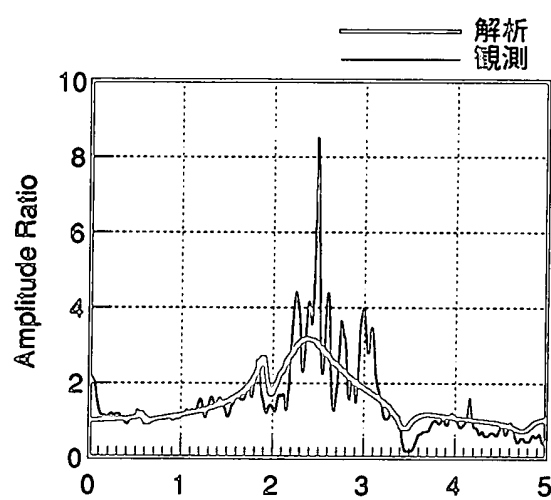

(c) 䞳物 B1F/ GL-27.5m 
$27.5 \mathrm{~m}$ の観測結果は、 $2.4 \mathrm{~Hz}$ 付近に地盤系と同様なピークがみられ、 建物の1 次 3 次に対応する振動数で多少变動している。解析結果 は 1 次、2 次の振動数における応答性状とよく対応している。建物 の 3 次振動数に相当する $3.5 \mathrm{~Hz}$ 付近では観測結果に鋭い落ち込み があるが、解析結果はあまり明暸ではない。この振動数は GL-13m
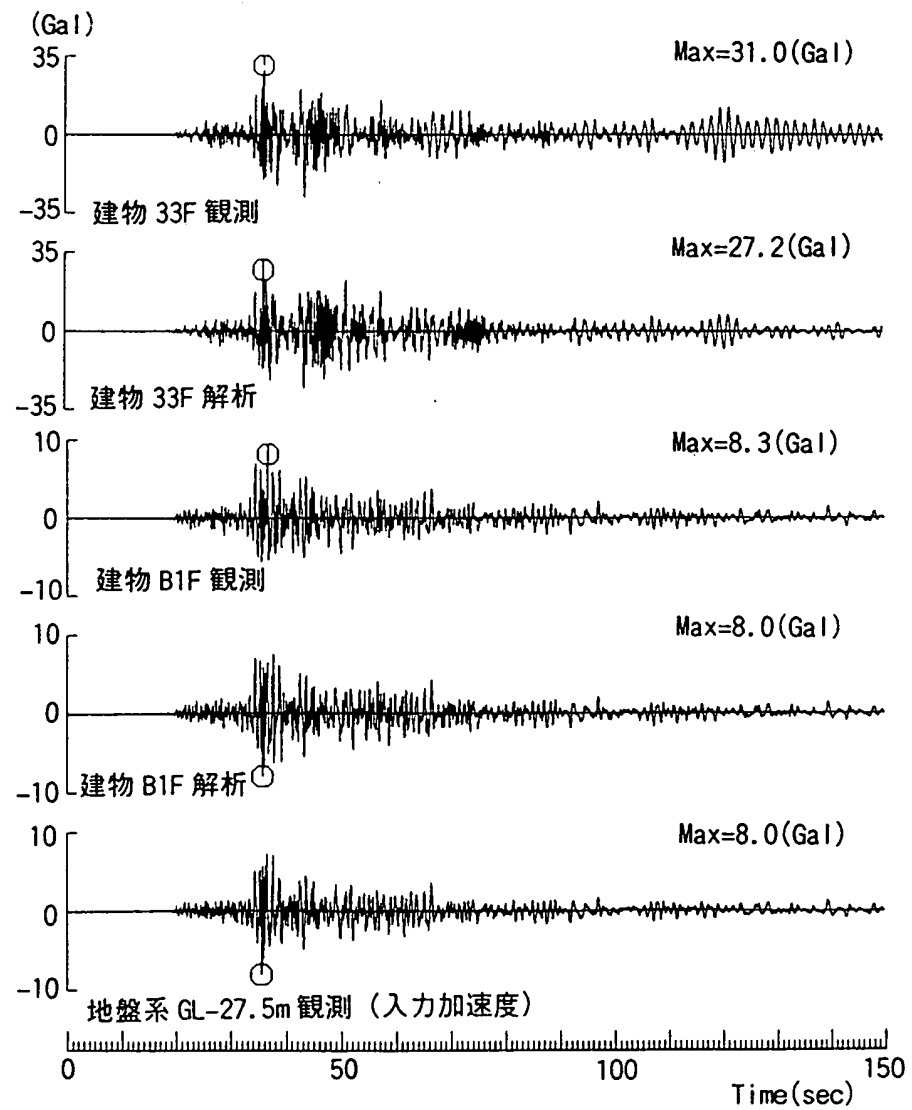

図 8 建物 33F,B1F の加速度波形と入力加速度波形
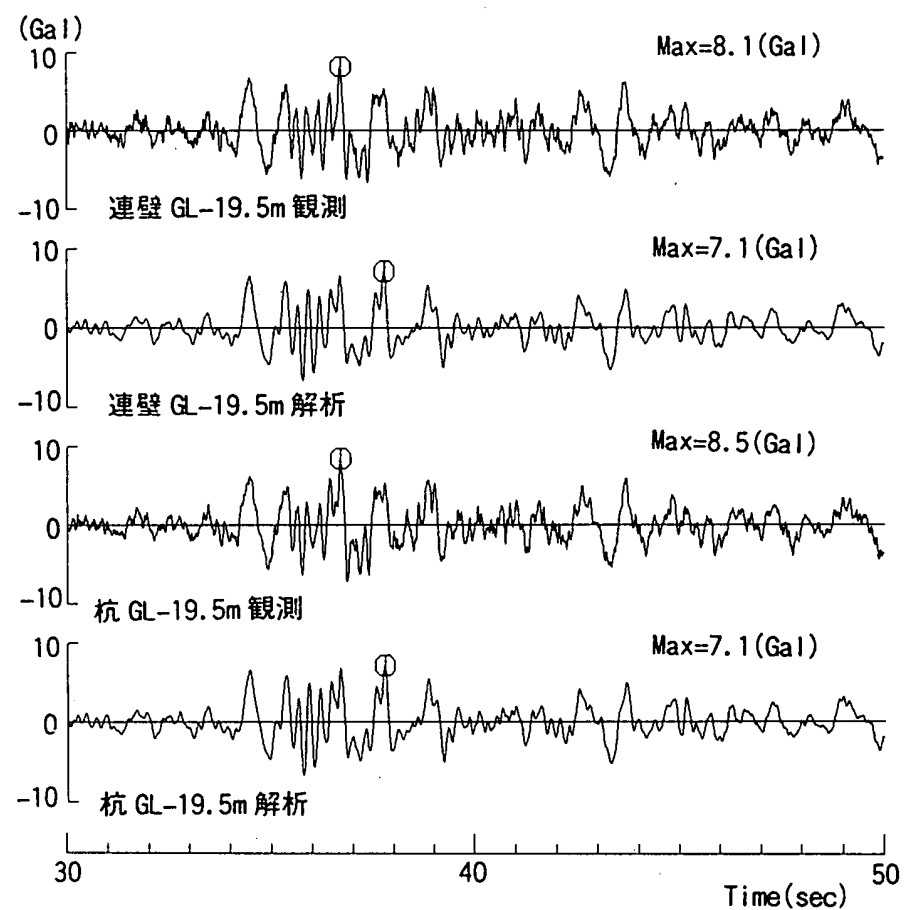

図 9 連壁と内部杭（GL-19.5m）の加速度波形
以浅の地盤の 1 次振動数にほほ対応しており、解析ではこの振動数 における地盤の振動モードを十分に表現できていないためと考え られる。

建物 33F とB1Fにおける加速度波形を解析結果と比較して図 8 に 示す。図中には、解析の入力波として用いた GL-27.5m の観測波形 も合わせて示した。建物 $33 \mathrm{~F}$ の応答振幅は、地盤系で主要動が終了 した後の 100 秒以降にも大きくなる部分がみられるが、入力波に含 まれる比較的長い周期の後続波成分により建物の 1 次周期が励起 されて応答が継続したと考えられる ${ }^{14)}$ 。解析結果は $33 \mathrm{~F}$ の最大加速 度值を小さめに評価しているが、観測波形の包絡形状、後続波に対 する応答ともよく対応していることが確認できる。

\section{2 複合基礎の地震応答}

連壁、内部杭の中間深さ位置 (GL-19.5m)の加速度について、その 主要動部分を解析波形と比較して図 9 に示す。連壁と内部杭の加速 度波形は非常によく対応した形状を示している。解析結果には観測 波形に含まれる高振動数成分はみられないが、連壁と内部杭の波形 とも観測波形の特徴をよく捉えている。図 10 に連壁、内部杭の中 間深さ位置 (GL-19.5m) の加速度のフーリエスペクトルを解析結果 と比較して示す。連壁、内部杭ともに $1 \mathrm{~Hz}$ 付近と $3.7 \mathrm{~Hz}$ 付近にピー クがみられる。これらのピークは地盤系の観測記録にもみられるピ 一クであり、観測地震波に含まれる卓越成分である。連壁と内部杭 の周波数特性もほほ同じ性状を示しており、解析結果は観測結果に みられる連壁と内部杭の応答性状とよく一致している。なお、解析 結果から連壁に囲まれた内部地盤についても連壁、内部杭と同様な

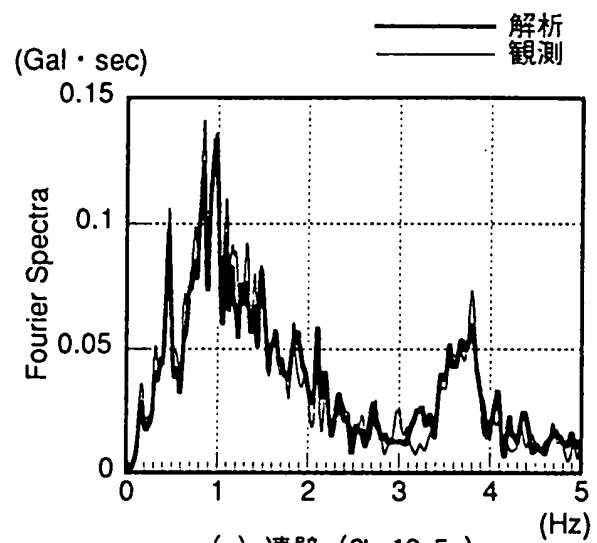

(a) 連壁 (GL-19.5m)

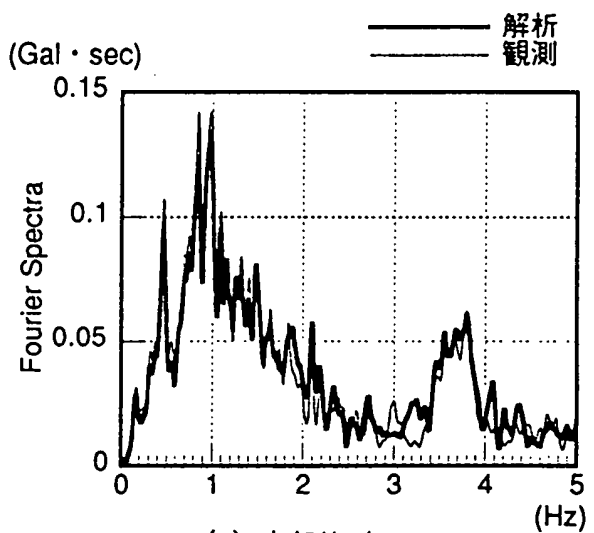

(b) 内部杭 (GL-19.5m)

图 10 連璧と内部杭（GL-19.5m）の フーリエスベクトル 
応答性状を示しており、内部地盤の応答が複合基礴により拘束され ていることが確認できている。

解析による連壁と杭の最大せん断力分布を図 11 に示す。地霞時 のせん断力は内部杭と外部杭での負担が少なく、そのほとんどを連 壁が負担している。連壁の応力は連壁の頂部よりも GL-19m〜GL-25m 付近の粘性土層で大きくなっている。次に、連壁頂部に近い位置 (GL-12.5m) と連壁の応力が大きい粘性土層位置 (GL-23.0m) につい て、上部建物および地下室部分を無質量とした応答解析から求めら れる地盤霞動による応力（Kinematic）と全体のせん断力（Total）

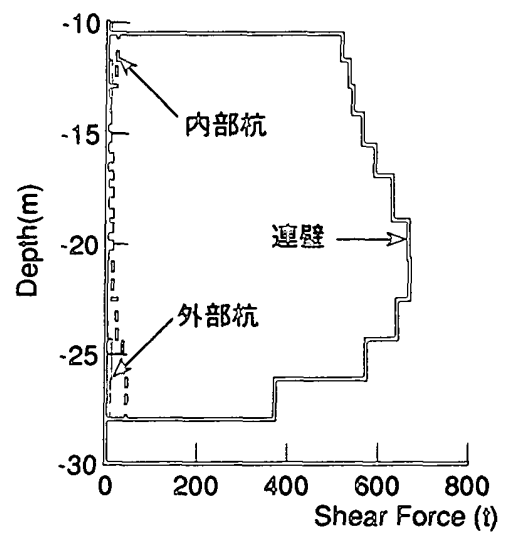

图 11 連壁と杭のせん断力分布
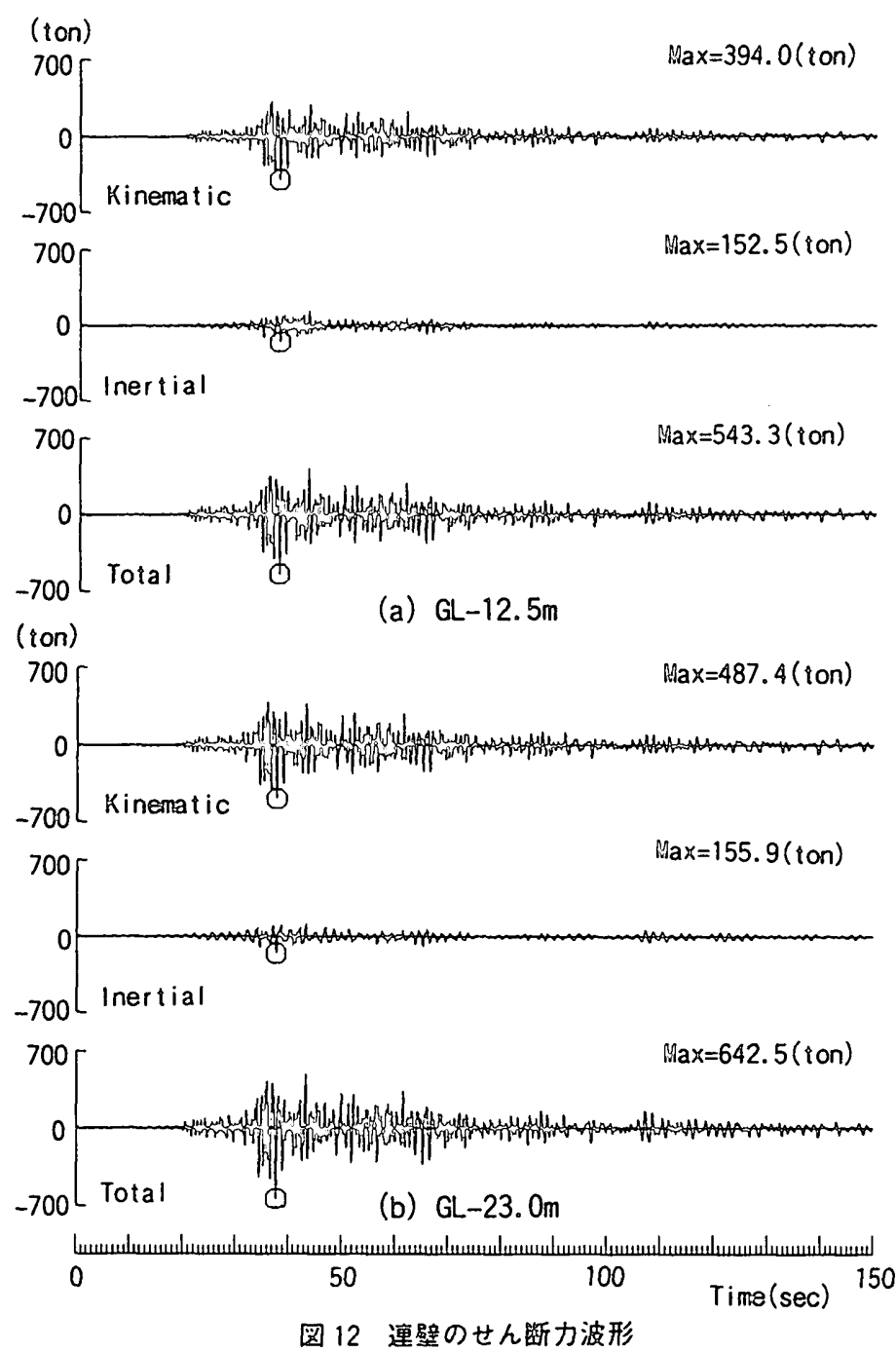

圆 12 墥壁のせん断力波形
から地盤震動による応力を時刻歷で差し引いて求めた建物の慣性 力による応力（Inertial）とに分離して検討する。得られたせん断 力波形を図 12 に示す。両深度とも地盤霞動による応力が建物の慣 性力による応力に比べ大きくなっており、最大值では GL-12.5m で 2.6 倍、GL-23.0m で 3.1 倍となっている。この理由として、上部棈 造の慣性力によるせん断力は地下室側面の地盤に流れるため、上部 構造から連壁に伝わるせん断力が少なくなること、連壁の剛性が比 較的大きいため地盤との変形差が大きくなり地盤震動による応力 が大きくなること等が挙げられる。また、連壁の応力が GL-19m〜 GL-25m 付近の粘性土層で大きくなる理由は、地盤剛性が上下の層 に比べ小さい粘性土層では地盤変形が大きくなり、地盤霆動によっ て生じる応力が增大するためと考えられる。図 13 にこれらのせん 断力波形のフーリエスペクトルを示す。両深度とも建物の慣性力に よる応力は建物の1次，2次振動数において大きくなっているが、 その他の振動数では地盤霞動による応力が支配的である。

このように、建物からの慣性力による応答に加え地盤震動による 応答が生じる地震時にも連壁、内部杭はほほ同じ挙動を示すことが 認められた。また、地震時に複合基整に生じるせん断力はそのほと んどを連壁が負担すること、連壁に生じるせん断力は地盤霞動によ る応力が大きいことがわかった。

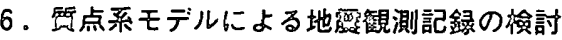

複合基碛の地震応答解析モデルとして、既報 ${ }^{11}$ では内部杭の剛性

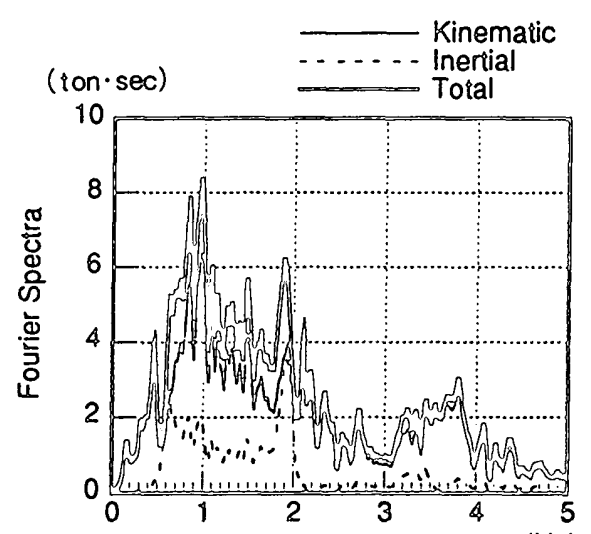

(a) $\mathrm{GL}-12.5 \mathrm{~m}$

$(\mathrm{Hz})$

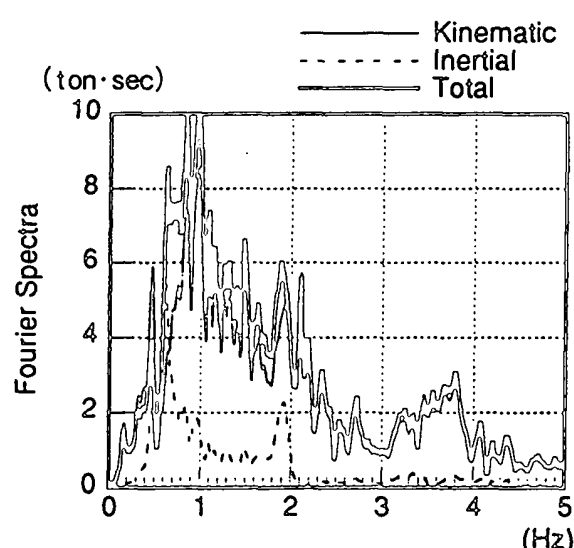

(b) GL-23.0m

$(\mathrm{Hz})$

图 13 㖶照のせん断力波形の フーリエスペクトル 


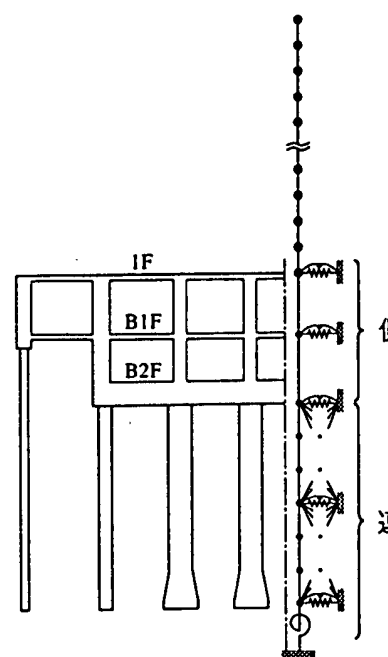

图 14 貿点系モデル

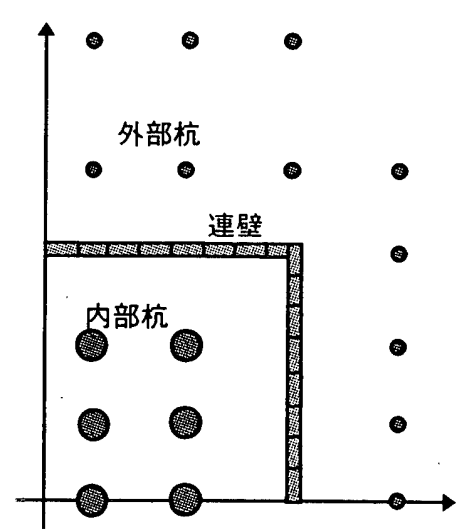

図 15 地盤剛性計算時の要素分割（平面）

を無視し連壁と内部杭を 1 本の曲げせん断要素でモデル化した図 14 に示す質点系モデルを提案した。本論文では、内部杭の挙動も 検討対象とすることと外部杭の寄与を取り込むため、既報の解析モ デルを一部改良して連壁と各杭に独立な自由度を与えたモデルを 用いて地震観測記録のシミュレーション解析を行った。

解析モデルでは、連壁を箱型断面の曲げ剛性（EI）とせん断剛性 （GA）を有する一本の曲げせん断要素 ${ }^{11}$ にモデル化した。内部杭と 外部杭は各杭毎に曲げせん断要素に置換し、平面的な位置を考慮し て地下室部の剛要素に接続している。各曲げせん断要素には連壁と 各杭との連成を考虑した地盤剛性マトリックス ${ }^{14)}$ を接続した。さら に、地下室部の各質点には埋込み基礎の側面ばね (水平と回転) ${ }^{15)}$ を付加した。連壁、杭の地盤剛性マトリックスの算定は、連壁上端 を地表面とした薄層要素法の点加振解 ${ }^{16)}$ を用いて評価した。地盤剛 性マトリックス算定時の離散点は、図 15 に示す平面的位置で深さ 方向に 10 分割した節点とした。各節点で水平と上下方向の自由度 を考慮して地盤の禿性マトリックスを評価した後、連壁部について は同一深度毎に平面保持を仮定して、水平と回転の自由度に集約し た。なお、既報 ${ }^{11)}$ では連壁下端の回転ばねを別途評価したが、本論 文では、連壁下端の上下方向自由度に基づく回転成分が、上記の地 盤剛性マトリックス中に組み込まれている。

質点系モデルへの入力は、GL-27.5m を入力位置とし、地表面レ ベルまでをモデル化してー次元波動論 (SHAKE) により求めた自由 地盤応答とし、上記の周波数依存の地盤剛性マトリックスを用いた
$\operatorname{Max}=31.0(\mathrm{GaI})$
$\operatorname{Max}=28.9(\mathrm{GaI})$

\section{解析（貿点系モデル）}

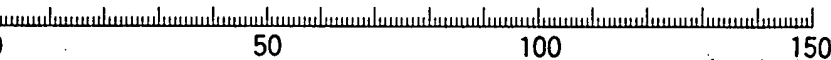

图 16 建物 33F の加速度波形

Time (sec)

籍虔视

モデル

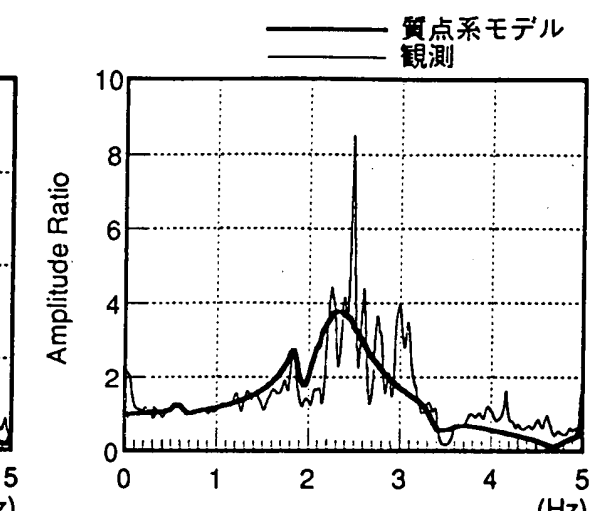

(b) 建物 B1F/ GL-27.5m

图 17 フーリエスペクトル比

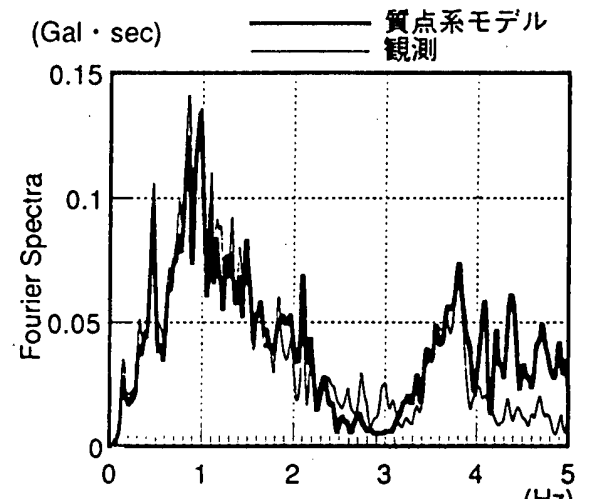

(a) 連壁 (GL-19.5m)

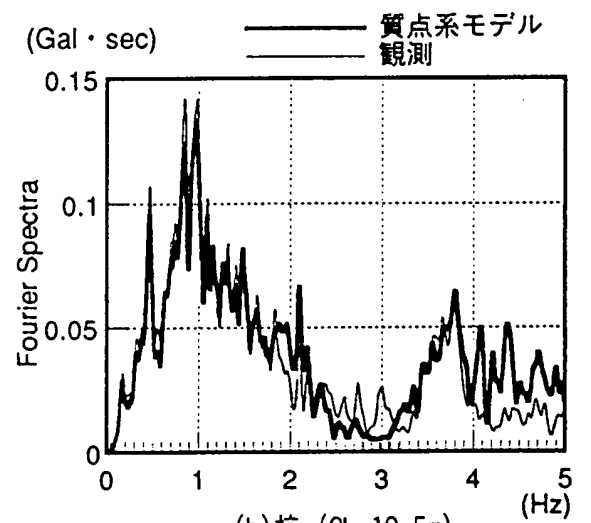

(b) 杭 (GL-19.5m)

图 18 連壁と内部杭（GL-19.5m）の フーリエスペクトル 
周波数応答解析により各部の応答を評価した。なお、地盤系の観測 波には複合基㗏の影餐が含まれているため、GL-27.5m 位置への入 力地霞波は、軸対称 F E M 用いて同深度の地盤系の観測波を自由 地盤の応答値に換算して用いた。なお、解析に用いた地盤定数と建 物系質点モデルは軸対称 F E M と同じである。

図 16 に建物 $33 \mathrm{~F}$ の加速度波形を解析結果と比較して示す。解析 結果は観測波形の包絡形状と振幅をよく捉えており、後続波部分で 建物の 1 次周期が励起される傾向がよく表現されている。図 17 に GL-27.5m 位置の入力波に対する建物 $33 \mathrm{~F}, \mathrm{~B} 1 \mathrm{~F}$ のフーリエスペクト ル比を解析結果と比較して示す。33F/GL-27.5m の解析結果は、図 7 の軸対称 F E M の解析結果と同様に建物の】次ピークで若干小 さめ、2 次ピークで若干大きめであるが、建物の応答性状をよく捉 えている。B1F/GL-27.5mの解析結果は、観測記録にみられる $3.5 \mathrm{~Hz}$ 付近の鋭い落ち込みは十分に表現していないが、観測結果とほほ同 じ形状を示している。

図 18 に連壁、内部杭の中間深さ位置 (GL-19.5m) の加速度のフー リエスペクトルを解析結果と比較して示す。質点系モデルの解析に おいても連壁と内部杭は一体となって振動する性状を示している ことが確認でき、解析結果は観測結果によく対応していることがわ かる。このことから、内部杭の剛性を無視し連壁と内部杭を 1 本の 曲げせん断系に置換した既報 ${ }^{11)}$ のデル化によっても、複合基䂫の 地震時挙動を検討することが妥当であることが確認された。

\section{7.まと的}

連壁と杭を併用した複合基簉を有する高層建物の地震観測結果 および基䂵部分の強制加振実験結果について検討し、軸対称 F E M を用いて複合基礎とその内部地盤の動的挙動を検討した。また、質 点系モデルにより地䨩観測記録のシミュレーション解析を行い、そ の有効性を検討した。本研究で明らかになったことを以下にまとめ て示す。

(1) 強制加振実験結果の検討から、連壁内部地盤の固有振動は地下 室や内部杭が存在することにより抑制され、連壁と内部杭はほぼ同じ 振動モードを呈すること、外部杭の存在は剖性と逸散減衰の增大に 影響することがわかった。さらに、地震観測記録の㭘討からも、 連壁と内部杭は同様な応答性状を示し、内部地盤の応答は複合基 磍により拘束さていることが確認された。また、連壁をシェル要素、内 部杭と外部杭をそれぞれリングパイル要素にモデル化した軸対称FE Mモデルによる解析結果は、これらの複合基䂣の応答性状とよく対 応することがわかった。

（2）複合基整の地筑時せん断力の分担割合は連壁部が支配的である ことが確諗された。また、連壁に生じる地震時応力は、連壁の どの深さにおいても地盤震動による応力が建物の慣性力による 応力に比べ大きくなることが明らかになった。これは建物の慣 性力によるせん断力が地下室側面から地盤に流れ建物から連壁 に伝わるせん断力が小さくなること、連壁の剛性が比較的大き く地盤霞動による応力が大きくなること等による。また、地盤 震動による連壁の応力は地盤剛性の小さい層付近で大きくなる ことがわかった。

（3）連壁と各杭に独立な自由度を与えた質点系モデルを用いて実施 した地霞応答解析結果は、複合基整および建物の地震観測結果
とよく対応し、質点系モデルの有効性が検証された。また、質 点系モデルによる解析結果においても連壁と内部杭は一体とな って振動し、連壁と内部杭を 1 本の曲げせん断系に置換した既 報 ${ }^{11)}$ のデル化によっても、複合基蕗の地霞時挙動を検討する ことが妥当であることが確認された。

\section{謝辞}

本研究を進めるに当たり、研究内容と結果の討議に参加頂き、貴 重な意見、方向性を呈示下さった鹿島建設の菅野忠博士をはじめ とする関係各位に感謝の意を表します。

なお、本研究は住宅・都市整備公団と鹿島建設との共同研究によ るものである。

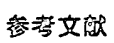

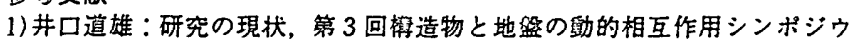
厶, pp.3 17, 1991.10

2) 若松邦夫，渡辺消治：WFくいによって支持された梅造物の地覀䂓湘，

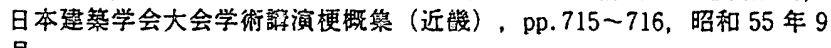
月

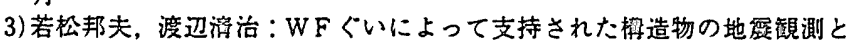

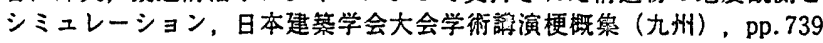
$\sim 740$, 昭和 56 年 9 月

4) 中川恭次, 渡辺滂治, 武田寿一ほか 4 名: WALL FOUNDATIONによって支 持された海造物の坵的解析に間する一考察（その1）解析仮定，（その

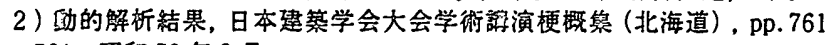
$\sim 764$, 昭和 53 年 9 月

5)阿部庰彦, 杉本三千雄, 犬趼伴幸ほか 3 名：ウォーターフロント地区に

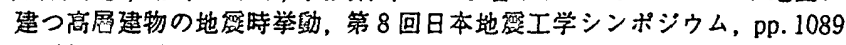
- 1094, 1990.9

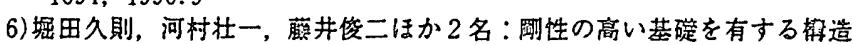
物と地盤との功的相互作用に閂する研究（その1）実駼概要，（その 2)

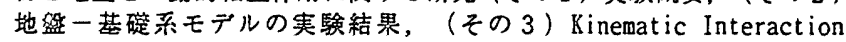
Inertial Interaction, 日本建等学会大会学術劷演梗概息（近幾）, pp. $971 \sim 976$, 昭和 62 年 10 月

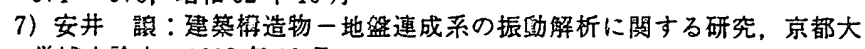
学博士諭文, 1983 年 10 月

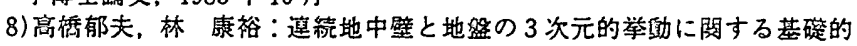

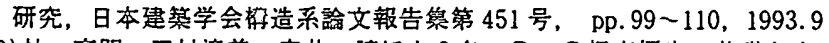

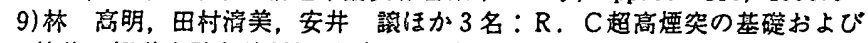

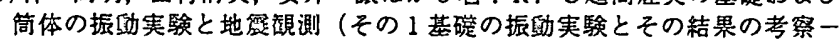

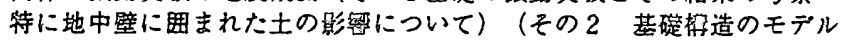

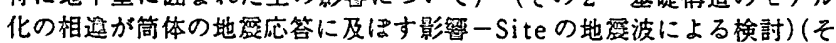

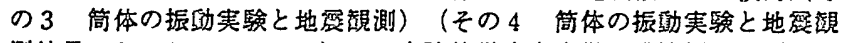

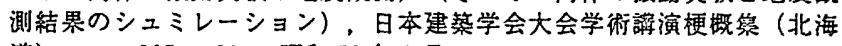
道) , pp. $807-814$, 昭和 53 年 9 月

10)津川恒久，福濞栄治，奥津一雄ほか1名：30階建鉄筋コンクリート造

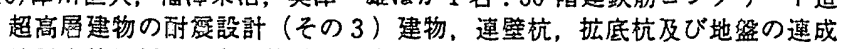

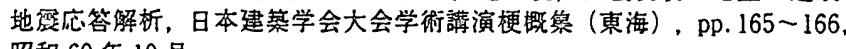
昭和 60 年 10 月

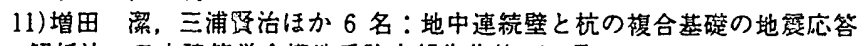
解析法, 日本建等学会博造系諭文報告舜第 437 号, pp. $41 \sim 49,1992.7$

12) Tyson, T.R. and Kausel, E. :Dynamic Analys is of Axisymetric Pile Groups, M.I.T. Department of Civil Engineering, Order No.751, 1983.6

13)酒向裕司, 宮本裕司ほか3名: 地中連続壁と杭の襀合基碳の動的相互 作用, 第 9 回日本地舞工学シシポジゥム, pp. 1165 1 1170, 1994.9

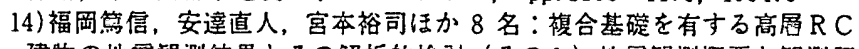

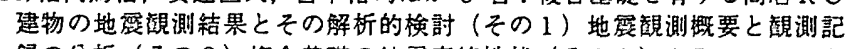

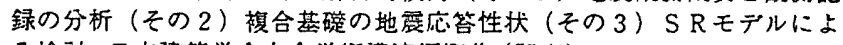

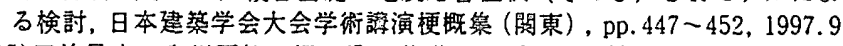

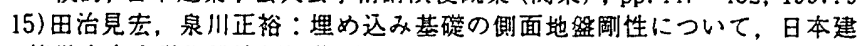
等学会大会学術暲演浭概集（北海道），pp.591－592，1986.8

16) Kausel, E. and Peek, R. :Dynamic Loads in the Interior of a Layered Stratum-An Explicit Solution. Bulletin of the Seismological Society of America, Vol.72, pp. 1459 1481, 1982

（1997年 7 月 10 日原稿受理，1997年10月23日採用決定） 